\title{
Improving livelihoods, training para-ecologists, enthralling children: Earning trust for effective com- munity-based biodiversity conservation in Andasibe, eastern Madagascar
}

\author{
Rainer Dolch, Jean-Noël Ndriamiary, Tianasoa \\ Ratolojanahary, Mad Randrianasolo, Irène Augustine \\ Ramanantenasoa
}

\author{
Correspondence: \\ Rainer Dolch \\ Association Mitsinjo, Andasibe, Madagascar \\ E-mail: rainer@mitsinjo.org
}

\begin{abstract}
The rainforests of eastern Madagascar are shrinking due to population growth, poverty-driven land degradation and widespread ignorance of ecological dynamics. This has resulted in large-scale transformation and fragmentation of these forests, threatening their unique biodiversity. Many of these problems are also manifest in and around the village of Andasibe. Based on the example of Association Mitsinjo, and drawing from more than a decade of experience of community-based natural resource management in Andasibe, we highlight the challenges and successes of a community-run conservation organization that builds trust through a holistic approach resting on five building blocks: (i) management transfer of natural resources to the local community, (ii) community-based nature tourism, (iii) training of para-scientists, (iv) rainforest restoration and improving local livelihoods, and ( $V$ ) environmental education. This has resulted in the creation and legal protection of two community-run reserves, Analamazaotra and Torotorofotsy, accompanied by ecological monitoring programs. We illustrate how handing over responsibilities to local communities can be a promising approach to conserving natural resources and biodiversity in Madagascar and elsewhere.
\end{abstract}

\section{RÉSUMÉ}

La superficie des forêts tropicales de l'est de Madagascar diminue avec la croissance démographique, la dégradation des terres par effet de la pauvreté, ainsi que par l'ignorance générale des interrelations écologiques. Tout cela a abouti à une transformation profonde et étendue ainsi qu'à la fragmentation de ces forêts qui menacent leur biodiversité. Ces problèmes globaux sont pour la plupart rencontrés à la périphérie du village d'Andasibe. Ici, l'exemple de l'Association Mitsinjo est présenté avec plus d'une décennie d'expérience en gestion communautaire des ressources naturelles à Andasibe. Sont ainsi exposés les défis et les succès d'une organisation de conservation gérée par la communauté qui gagne la confiance à travers une approche posée sur cinq piliers : (i) le transfert de gestion des ressources naturelles à la communauté locale, (ii) l'écotourisme à base communautaire, (iii) la formation de para-scientifiques, (iv) la restauration de la forêt tropicale humide en augmentant les moyens de subsistance des gens vivant sur la périphérie, et (v) l'éducation environnementale. Les actions entreprises ont abouti à la création et la protection efficace de deux réserves gérées par la communauté, accompagnées de programmes de surveillance écologique. Grâce à la responsabilisation des collectivités locales dans la protection de la biodiversité, elles montrent une fierté des actions entreprises qui est un indice prometteur pour la conservation des ressources naturelles et de la biodiversité à Madagascar et ailleurs.

\section{INTRODUCTION}

community-based natural resource management (CBNRM) is a concept that attempts to integrate conservation objectives with improved livelihoods for rural communities (Salafsky and Wollenberg 2000). About 20 years ago, Madagascar endorsed this concept through a legal mechanism called transfert de gestion, which was designed to allow local communities to manage their own natural resources sustainably. However, patterns of natural resource use by local communities often appear difficult to reconcile with positive outcomes for biodiversity (Kellert et al. 2000, Hockley and Andriamarovololona 2007). Many CBNRM initiatives seem to lack true empowerment of local communities, while local communities tend to only conserve resources if the immediate benefits from conserving them exceed the cost of their conservation (Toillier et al. 2011). Differing interests between local communities and conservation organizations involved in CBNRM may result in conflict over time (Raik and Decker 2007, Scales 2012).

Here we present a case study focusing on CBNRM activities implemented by Association Mitsinjo, a community-based conservation organization working in the region of Andasibe in central eastern Madagascar. Association Mitsinjo came into being in 1999 as a grass-roots initiative from Andasibe village. Originally founded as a union of local wildlife guides, the association's members focused on guiding wildlife tourists. Conscious of the fact that wildlife tourism requires effective protection of wildlife, Mitsinjo soon began to expand the scope of its activities, ultimately transforming the association into a local conservation organization. 


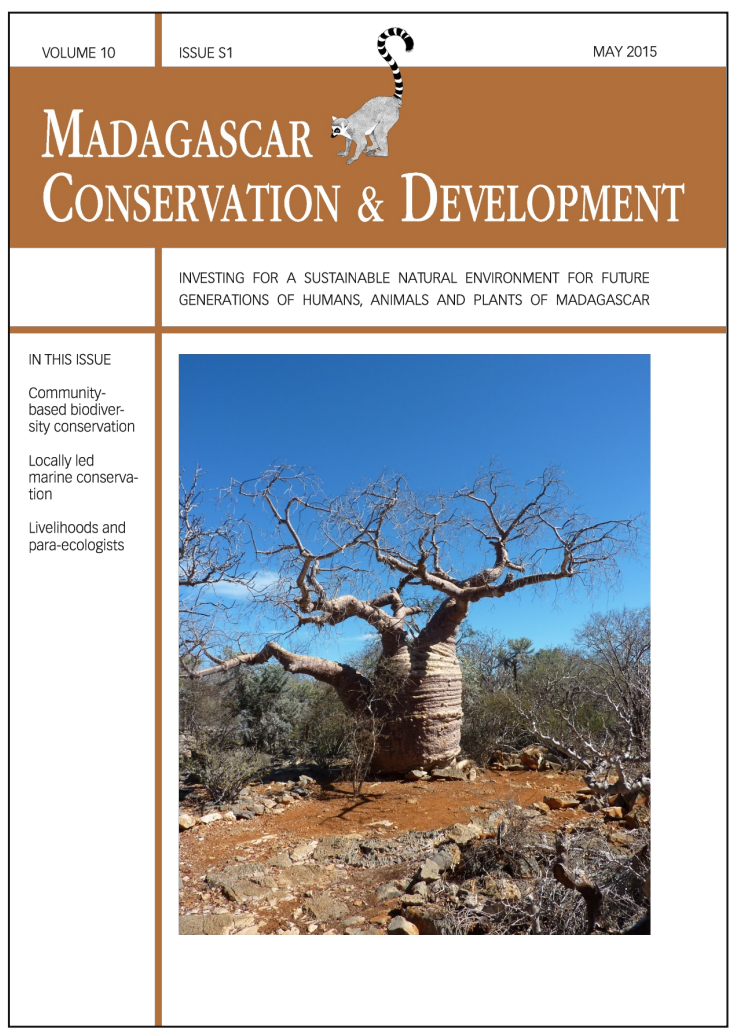

Madagascar Conservation \& Development is the journal of Indian Ocean e-Ink. It is produced under the responsibility of this institution. The views expressed in contributions to MCD are solely those of the authors and not those of the journal editors or the publisher.

All the Issues and articles are freely available at http://www.journalmcd.com

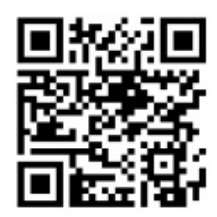

Contact Journal MCD

info@journalmcd.net for general inquiries regarding MCD funding@journalmcd.net to support the journal

Madagascar Conservation \& Development Institute and Museum of Anthropology

University of Zurich

Winterthurerstrasse 190

$\mathrm{CH}-8057$ Zurich

Switzerland

Indian Ocean e-Ink

Promoting African Publishing and Education

www.ioeink.com

Missouri Botanical Garden (MBG)

Madagascar Research and Conservation Program

BP 3391

Antananarivo, 101, Madagascar 
Governed by Malagasy law (Ordonnance 60-133), all executive duties and responsibilities are entirely assumed by Mitsinjo's members, who are all members of the local community and live in Andasibe. In 2002, they actively sought support for the coordination of their CBNRM activities, which has since been assumed by one (later two) non-Malagasy inhabitant(s) of Andasibe, after having been an integral part of the community for several years. Having grown to more than 50 members over the 15 years of its existence, Mitsinjo's management board is exclusively Malagasy. Decisions within Mitsinjo are taken by a majority vote of the management board. The management board consists of a president, vice-president, secretary, treasurer and three advisors. The role of Mitsinjo's non-Malagasy coordinator is to maintain contact with partners and potential donors, as well as to propose new projects and/or funding opportunities to the association's management board, which will decide on projects to pursue. The president, treasurer and coordinator collaborate on proposal and grant writing. While the coordinator has a supervising role, the president takes the lead for implementing any projects. Strategic decisions and the budget are approved or rejected through democratic vote by the bi-annual general assembly.

Mitsinjo's activities focus on Andasibe's areas of high biological value and the local communities living in and around them. Most members of these communities are disadvantaged and highly dependent on natural resources. Mitsinjo promotes conservation activities (e.g., rainforest restoration, ecological monitoring) and provides basic social services (income, food, health) for the local community, highlighting alternative livelihoods and strategies for long-term sustainable development. At the same time, educating people about basic ecological concepts and raising awareness about both the spiritual and economic values of nature and biodiversity will hopefully further reduce pressure on natural resources. Activities mainly concentrate on two sites of conservation importance in Andasibe commune, Station Forestière Analamazaotra and Torotorofotsy Ramsar site. While the former is immediately adjacent to Andasibe-Mantadia Nationa Park, the latter is proposed as a new protected area within Madagascar's Protected Area system or Système des Aires Protégées de Madagascar (SAPM).

\section{STUDY SITE}

The village of Andasibe in central eastern Madagascar lies a threehour drive east of the country's capital, Antananarivo. Situated in one of Madagascar's conservation priority areas (e.g., Kremen et al. 2008), Andasibe's forests are exceptionally rich in biodiversity, from plants, to arthropods and vertebrates. Apart from several dozen species of ferns, the flora of Andasibe comprises about 800 species of angiosperms (ANGAP 1995), including the extremely rare palm Ravenea louvelii, a local endemic species that does not occur anywhere else (Dransfield and Beentje 1995). The vertebrates are represented by 70 species of reptiles, 90 species of birds, and a diverse assemblage of carnivores (Dolch 2012). Two groups, the lemurs and frogs, are exceptionally diverse. The forests of Andasibe are home to 13 species of lemurs (Dolch et al. 2013, IUCN 2014), four of which are Critically Endangered: the greater bamboo lemur (Prolemur simus), the black-and-whiteruffed lemur (Varecia variegata), the diademed sifaka (Propithecus diadema), and the indri (Indri indri). With its impressive and loud territorial songs (Giacoma et al. 2010), the indri is surely the most spectacular of all and has consequently become an icon for the Andasibe region. Less known, Andasibe also hosts one of the most species-rich amphibian assemblages of the world. More than a hundred species occur here (Glaw and Vences 2007), including the Critically Endangered Mantella aurantiaca, as well as a plethora of other charismatic species exhibiting exceptional ecological, morphological, and reproductive diversity (Andreone et al. 2008).

Andasibe has become one of Madagascar's most popular tourist destinations early on, mainly because of its exceptional wildlife viewing opportunities close to the country's capital. Numbers of both foreign and Malagasy visitors steadily increase, and Andasibe has become one of the most visited destinations of the country (Newsome and Hassell 2014). As a consequence, numerous hotels and lodges have sprung up in the vicinity, accommodating approximately 30,000 visitors annually.

Unfortunately, only a minority of Andasibe's inhabitants (hotel staff, guides) benefits from the tourism boom, despite considerable revenue generated from it (pers. observ.). Only little money actually trickles down to the rest of the population, since most items needed by the local hotels (construction materials, machinery and even most foodstuffs) are not sourced from within the community but from Moramanga or even Antananarivo. Moreover, villagers have long expressed and continue to express discontent about the allocation of visitors' entrance fees, which, in their view, appear to be used up by the national park's administration, rather than being reinvested into the local community.

As a consequence, most inhabitants of Andasibe are obliged to generate their income from other sources than tourism. The timber industry (together with the mining industry that began to exploit the area's graphite deposits in the 1940s), remained the principal employer well after independence (Ballet et al. 2011). continuous and short-sighted exploitation of forest resources finally led to the decline of the last industrial sawmill, the Complexe Industriel de Bois d'Andasibe (CIBA), which ceased to operate in the early 1990s. Shortly afterwards, the near-surface graphite deposits were depleted and most of Andasibe's workforce became unemployed. Given the loss of employment opportunities, as well as the unequal distribution of income generated through tourism, many of Andasibe's inhabitants remain desperately poor, subsisting on meager forms of agriculture for a living (such as hill rice production after slash-andburn), or the extraction of natural resources from Andasibe's everdwindling forests, such as through charcoal production, logging, hunting and artisanal mining. All these activities are not only detrimental to the environment, having contributed to the loss of vast tracts of rainforest and the resultant loss of biodiversity over the years (Irwin et al. 2010), but are also unable to help break the vicious circle of poverty and the degradation of natural resources. Poor households at the forest boundary can only cultivate small areas of land. This appears to favor patterns of land use that perpetuate low agricultural productivity and trap households in poverty (Angelsen and Wunder 2003, Coomes et al. 2011).

\section{OBJECTIVE AND APPROACH}

The principal objective of Mitsinjo is to integrate biodiversity conservation with rural development in order to improve livelihoods. Working to achieve this goal, Mitsinjo's holistic approach is based on five building blocks: (i) management transfer 
of natural resources to the local community; (ii) community-based nature tourism; (iii) training of para-scientists; (iv) rainforest restoration and improved local livelihoods; and (V) environmental education.

MANAGEMENT TRANSFER OF NATURAL RESOURCES. Entitling the local community to their natural resources is a prerequisite for successful community-based natural resource management. According to national law, management of natura resources can be transferred to local communities if they are organized in associations (Toillier et al. 2009, King et al. 2013), usually referred to in Malagasy as vondron'olona ifotony (VOI). The respective French acronyms are CLB (communauté locale de base) or COBA (communaute de base), depending on the two types of natural resource management transfer. The former are beneficiaries of GELOSE (gestion locale sécurisée), while the latter are beneficiaries of GCF (gestion contractualisée des forêts). GCF is a more straightforward way of transferring natural resources to local communities and can also be applied to forests under the control of the Ministère de I'Environnement, de I'Ecologie, de la Mer et des Forêts (MEEMF) (Pollini et al. 2014). In 2002, Mitsinjo signed a GCF contract and took over the management of the Station Forestière Analamazaotra (Dolch 2008). After evaluation by MEEMF, the initial contract has subsequently been changed into a lease contract (location de gérance) in 2007, with a validity period of 30 years.

Experience gathered by Mitsinjo's members in communitybased management of SF Analamazaotra has extensively been shared with VOI Taratra of Torotorofotsy, resulting in a GELOSE contract for the latter with respect to the management of the natural resources of the area and, ultimately, the designation of Torotorofotsy as a Ramsar site in 2005 (Ramsar Convention 2012). Mitsinjo has been supporting community-based management efforts in Torotorofotsy ever since and has subsequently been appointed as the entity responsible for the implementation of the management plan of the Ramsar site by the MEEMF.

COMMUNITY-BASED NATURE TOURISM. It has been shown that only very few VOIs - due to insufficient external support needed to help secure a sustainable source of revenue - are economically viable (Hockley and Andriamaravololona 2007). One sustainable economic activity that is likely to fetch considerably higher income than conventional (i.e., destructive) practices is nature tourism. If well designed, it is an environmentally-friendly source of income with the greatest potential for significant returns to local communities in Madagascar (Pawliczek and Mehta 2008, Jensen 2010). Given its roots as a union of wildlife guides, Association Mitsinjo has embraced nature tourism as a source of income from the beginning. A network of nature trails has been established in the SF Analamazaotra and several circuits - both diurnal and nocturnal - are offered to visitors. Proceeds from visitors' fees benefit both the individual guide and the association itself, according to a jointly-defined ratio. Regular training sessions are provided for both senior and junior guides in collaboration with the national guide association or similar organizations. Through regular exchange of experience with fellow guides and critical reflections by their peers, guides are constantly trained while executing their duties - a recommended practice to maintain and improve the quality level of services provided.
About a third of Mitsinjo's annual budget is generated through income from nature-based tourism. This has enabled the association to maintain and improve tourism infrastructure through the construction of various facilities, including a reception, a restroom, several shelters for camping and a handicraft shop. The resultant income is also used to employ and pay additional staff, such as receptionists, handicraft vendors, housecleaners, carpenters, and patrolling/monitoring agents.

Moreover, income for guides and other staff benefits the local community both directly through money for their families, and indirectly through their increased purchasing power. This also helps to create a sense of pride in the natural environment among local people who recognize the attractive uniqueness of their forest and realize the fundamental importance of preserving it as a viable source of income. The local community further benefits from the possibility to produce and sell high-quality handicraft through the association's curio shop, thus also providing income for members of the local community who are not members of the association.

Experience gathered in community-based nature tourism is widely shared with other local communities, mainly with the aforementioned VOI Taratra of Torotorofotsy, who have benefitted from the construction of nature trails and bungalows in the area managed by them. Mitsinjo has provided training to other guides in the Andasibe region and elsewhere in Madagascar, from Fetraomby to Vohibola to Anjajavy.

TRAINING PARA-SCIENTISTS IN COMMUNITY-BASED MONITORING. When the association embraced nature tourism as a major income provider, particular attention was given to permit unobstructed observation of Andasibe's iconic flagship species, the indri, in the two managed sites. Habituating wild groups of indri to frequent visitors was a major challenge, given the animals' initial fear of humans and associated flight distance. In order to achieve this, the association relied on a couple of community members with an exceptional knowledge of the forest and its animals. Interestingly, some of these people were formerly required to earn their living through hunting lemurs and other animals out of economic necessity. It has provided them with an enormous sense of appreciation that the project now enables them to use their vast understanding of nature for conservation purposes.

The intimate knowledge of the forest has also caused them to be sought after by both Malagasy and foreign scientists, although none of them have a scientific academic background. Assisting visiting scientists from all over the world, they have essentially contributed to research on a plethora of taxa, including primates (Giacoma et al. 2010, Junge et al. 2011, Torti et al. 2013), reptiles (Wallach and Glaw 2009), amphibians (Woodhead et al. 2007), invertebrates (Cliquennois 2007, Wesener and Schütte 2010), plants (Janssen and Rakotondrainibe 2008), and mushrooms (Pirot 2006), to name but a few. In this process of mutual learning, they have become acquainted with almost all aspects of the natural sciences, and comprehensively trained in related scientific methodology. While merging traditional and scientific knowledge, these community members have become invaluable para-scientists, and some of them have embarked on their own research projects (e.g., Fiely 2010, Ratolojanahary 2011). 
The association's local knowledge is not only used for monitoring indri populations, but was also crucial in the remarkable discovery of new populations of the greater bamboo lemur (Prolemur simus) in the area (Dolch et al. 2008, Ravaloharimanitra et al. 2011). The association's para-scientists started gathering baseline scientific data and monitoring the Torotorofotsy population and ecology of this Critically Endangered species, which resulted in attracting considerable funding from conservation donors. It is a prime example of how including loca communities in research and monitoring programs contribute to both conservation and the generation of revenue.

community-based ecological monitoring led by the association's para-scientists is currently focusing on lemurs, birds and frogs in the Torotorofotsy Ramsar site. This helps improve management decisions as well as the livelihoods of community members that are employed as monitoring agents. Moreover, the association's para-scientists share their experience and have contributed through training other local communities to monitor their animal populations and eventual threats to them (e.g., Randrianarimanana et al. 2012).

We believe that delegating responsibility for monitoring and research to community members has created a feeling of pride and appreciation. Based on local capacities and in compliance with the national strategy for amphibian conservation (known as the Sahonagasy Action Plan), Mitsinjo has spearheaded the construction and operation of Madagascar's first captive breeding center for endemic amphibians (Edmonds et al. 2012). Executed in collaboration with governmental institutions and the IUCN, it is entirely community-based and run by Mitsinjo's technicians. The goal is to gather knowledge of local frog species' reproduction practices from various ecological guilds, and to establish captive assurance colonies of threatened frog species from the Andasibe region. Frogs and their insect food sources are maintained and bred in a bio-secure facility. It is hoped that it will serve as a mode for similar facilities and become a center for training and education to share knowledge and expertise gained from other organizations and institutions in Madagascar.

RAINFOREST RESTORATION AND IMPROVED LOCAL

LIVELIHOODS. Empowerment, increased experience and accumulated scientific knowledge have also been crucial in successfully implementing Mitsinjo's rainforest restoration activities. Mitsinjo members have planned and established the first tree nursery in 2002 with the goal to produce seedlings of native rainforest trees in order to restore areas of Analamazaotra forest previously destroyed through charcoal burning and swidden agriculture. In-training experience acquired during that period (e.g., seed collection, nursery and planting techniques) could subsequently be used for the ambitious TAMS Project (tetik'asa mampody savoka), a flagship project incorporating rainforest restoration, re-establishing habitat connectivity, and effecting carbon sequestration (Paiva and Randrianarisoa 2010). Mitsinjo spurred the ground work through the identification of suitable land for reforestation while negotiating with local farmers willing to set aside part of their land for rainforest restoration. This led to the establishment of five community-run tree nurseries which produced tens of thousands of native rainforest trees in up to 150 different species during peak production. The local community has benefitted from training in nursery and planting techniques provided by Mitsinjo staff. Although the TAMS Project was unfortunately hampered by an plethora of stakeholders and internal turf wars (Pollini 2009), the number of native rainforest trees planted (more than one million) was nevertheless impressive. This corresponds to slightly more than 1,000 ha of restored rainforest, with about 350 ha restored by Mitsinjo alone. It was hoped that carbon credits generated through photosynthetic carbon sequestration would be traded in order to provide for sustainable direct payments to farmers having set aside parts of their land for forest restoration, but the original Emission Reductions Payment Agreement with the World Bank's BioCarbon Fund has subsequently been suspended.

Restoring rainforest also contributes to reduced erosion, improved water retention, promotion of pollinators, and microclimatic equilibrium. These ecological services all have the potential to contribute to increasing agricultural performance and livelihoods of the local community in the long term. Indirect benefits from reforestation are accompanied by other activities designed to directly improve local livelihoods. In order to achieve this, Mitsinjo is particularly focusing on improved agriculture and community health, as well as the social infrastructure associated with it.

Mitsinjo has supported the establishment of organized farmer groups throughout Andasibe commune, with a special focus on the remote hamlets and deprived scattered settlements in Torotorofotsy to build both the capacity and the production potential of the local community. Collaboration with farmer groups and village associations was strengthened through the Sustainable Livelihood Activities (SLA) component of the TAMS Project. The objective was to provide economically viable alternatives to the traditional practice of slash-and-burn agriculture or tavy (Coutinho 2007). Various micro-projects were implemented, aimed at improving agricultural diversity, production and income. They have been developed along the establishment of relevant demonstration plots focusing on agroforestry, fruit trees, mixed plantations, and permaculture. Several plots have been established in the vicinity of reforested land in order to reward farmers for having set aside part of their land for rainforest restoration. Moreover, Mitsinjo's community-based trainers have freely distributed seeds (rice, beans, sorghum, potatoes) and agricultural materials (plows, shovels, rakes), and regularly provide trainings for local farmers (every six months on average) on rice cultivation, vegetable gardens, agroforestry, cattle breeding and apiculture, among others. In collaboration with the US Peace corps, emphasis was placed on increasing sustainable rice production through the extension of the so-called système de riziculture intensif (SRI). As this technique usually provides higher yields from the same area of plowed land, Mitsinjo chose to promote it as a way to reduce the demand for conversion of wetlands to rice paddies, while increasing food security. Since all households involved in this program barely produce enough rice for subsistence (let alone for sale), we assume that the risk of converting more natural vegetation into arable land due to increased revenues (e.g., Gorenflo et al. 2011, Pollini 2012) would be limited.

Several projects focusing on community health were implemented thanks to Mitsinjo's adhesion to Voahary Salama, a network of Malagasy organizations sharing the philosophy of a Population, Health, and Environment (PHE) approach. These projects have led to the formation of a dozen community-based agents de sante à base communautaire (ASBC). The ASBC have 
since advised and informed the local community on a plethora of urgent and critical health issues. They have freely distributed hundreds of insecticide-treated mosquito nets to help fight malaria, chemical water purification kits to help combat diarrheal diseases, and free condoms to prevent sexually transmitted diseases (STDS) with special emphasis on HIV/AIDS. Raising awareness on STDS was coupled with raising awareness on family planning, offering women a variety of contraceptive methods, thus providing them with the choice of how many children they want to have. Sanitary infrastructure erected by Mitsinjo for the local community comprises numerous latrines and drinking water wells throughout Andasibe commune and beyond, as well as a dispensary at Torotorofotsy. This small clinic was inaugurated in 2013 by the Service Sanitaire de District (SSD), and will be operated by a professional nurse, assisted by the ASBC. Minor ailments and illness can now be treated on site due to having a dispensary, and people no longer need to travel to the clinics in Andasibe or even Moramanga, the district capital.

ENVIRONMENTAL EDUCATION. In order to raise environmental awareness and disseminate knowledge among the local community that would sustainably embed environmental thinking in the next generation, Mitsinjo has set up a comprehensive environmental education program for schoolchildren of the Andasibe region. In collaboration with the School District or circonscription scolaire (CISCO) and the superintendent of schools in the region or chef de la zone d'action pédagogique (Chef ZAP), Mitsinjo's environmental education program covers all seven elementary schools in Andasibe Commune, including six public primary schools or écoles primaires publiques (EPPS) and the private school St. Pierre et Paul of the Catholic Mission.

The person leading Mitsinjo's environmental education program is a local experienced teacher who has worked for various private primary schools as well as for the Alliance Française. She has been pedagogically trained and put together a team of twelve community-based voluntary teachers and developed an environmental curriculum together with the head teachers of all seven primary schools. Mitsinjo's voluntary teachers visit each primary school every week, teaching schoolchildren about the environment in a playful and interestgenerating way, carrying out activities that encourage them to have fun engaging with their environment, and to think critically about the importance of natural resources and biodiversity. At present, more than 300 schoolchildren (age 8-10) are enrolled in the program, which is the first of its kind implemented in the Andasibe area.

Additionally, schoolchildren are taken on theme-based excursions into the forests managed by Mitsinjo every two months, providing a hands-on fun activity for the children and enabling volunteers to explain things more vividly than it would be possible in a classroom. During these excursions, many of the children see lemurs such as indri for the first time in their life. Children are also taken out to participate at events like World Wetlands Day, World Biodiversity Day or World Environment Day. They most enjoy the reforestation activities, and tree-planting is embraced by schoolchildren as both a fun event and a way to manage the forest for their own futures. At the end of the school year, all seven schools take part in a casual competition to find out which class can best summarize what they have learned about the environment through song, dance, or acting. The competition is followed by concluding festivities.

Both teachers and schoolchildren appear to appreciate the program, as indicated through feedback. The children are enthusiastic, inquisitive, and eager to learn new things, which is crucial for them to explore the unique biodiversity of Andasibe and appreciate its importance. With continuous support from the Chef ZAP, the program will hopefully expand from the local primary schools to the middle school level, possibly benefitting from Mitsinjo's collaboration with the Madagascar Fauna \& Flora Group and their experienced educators from Parc Ivoloina in Toamasina. Currently, Mitsinjo provides environmental features in collaboration with Andasibe's local radio, Radio Vahiniala, to reach a wider audience and raise environmental awareness among parts of the population previously unreached.

\section{RESULTS AND LESSONS LEARNED}

In summary, community-based natural resource management coordinated by Mitsinjo has led to the legal protection and management of two sites of conservation importance (SF Analamazaotra, Torotorofotsy Ramsar site) that cover more than 10,000 ha in total. Thanks to Mitsinjo's regular patrols and assistance to local communities living adjacent to it, illegal logging and snare hunting virtually ceased since the association has taken over management for SF Analamazaotra. Although the situation at the Torotorofotsy Ramsar site is much more challenging (with about 2,000 people living within the site and additional immigrants because of the pipeline road of the Ambatovy nickel mine to the northwest), the regulations to use natural resources have improved thanks to a management plan that defines areas of conservation and areas of usage rights which are supervised and governed by local law (dina). At both sites, income generated from nature tourism directly provides for some 50 families of community members. Additionally, some 500 families, about a seventh of the population, benefit from projects focusing on rainforest restoration, agriculture and community health to improve their livelihoods. Based on feedback from farmers, the adoption of new agricultural techniques appears to have led to increased rice yields and a reduction of slash-and-burn practices. Training members of the community as para-scientists has led to community-run monitoring schemes, aimed at estimating population dynamics of certain vertebrate taxa (lemurs, birds, frogs) and identifying threats in a timely manner. Building sciencebased technical capacity has resulted in the creation of Madagascar's first captive breeding facility for amphibians and the restoration of habitat connectivity through the plantation of a million native rainforest trees. About 300 schoolchildren from all primary schools of the region are enrolled in an environmental education program, promoting conservation of biodiversity and sustainable use of natural resources. There is no doubt that such a holistic approach is absolutely essential for successful community-based natural resource management and conservation (Gruber 2010, but see also Rendigs et al. 2015). The Mitsinjo experience has shown that sustainable income generated from nature tourism, rainforest restoration, improved livelihoods through agriculture and health services, empowerment through training and experience and environmental education, were all helpful components to boost local conservation initiatives.

However, although Mitsinjo's activities benefit several hundred families, they still reach only a fraction of Andasibe's 
entire community (ca. 14,000 inhabitants). As a consequence, some community members feel marginalized and often perceive those community members that work for, or benefit from, Mitsinjo's activities as elitists. The feeling of not being able to have a share in the benefits can turn into frustration and even opposition. Moreover, a large percentage of the income generated in Andasibe traditionally comes from logging, which once provided most employment opportunities to the community. It continues to be a vital part of the local economy which individual timber traders now dominate, especially after the disintegration of the CIBA. These entrepreneurs (as well as their workers) naturally feel threatened by any activity that might negatively affect their business. They also do not appear to be interested in improving local livelihoods, since they benefit through the availability of cheap labor when people are unemployed. Empowering community members and providing economic alternatives is therefore crucial. Legally entitling them to manage their own resources is a prerequisite, although timber and charcoal remain the primary source of income of many community-managed forests in Madagascar, thus often contradicting conservation objectives (Hockley and Andriamaravololona 2007).

Even among community members that engage in Mitsinjo's conservation activities in Andasibe, conservation is not usually seen as a vital requirement for maintaining ecosystem services or supplying the community with renewable natural resources. For most community members it is an alternative but interchangeable way of earning their income. If conservation-related activities provide more income through direct employment or revenue otherwise generated, people are likely to engage in them. Since only a part of Mitsinjo's annual budget is self-financed, many conservation-oriented jobs other than wildlife guiding (such as tree planting or ecological monitoring) are still strongly dependent on temporary third-party funding. However, any disruption in a regular salary can result in people looking for other paid jobs again. If there is no sufficient income from conservation activities, community members might switch to something more promising, which in most cases is linked to extractive and environmentally harmful businesses. As a consequence, some members of the community have alternated between tree planting and logging, and others between handicraft production and charcoal burning. some of them would even engage in both environmentallyfriendly and environmentally-harmful activities at the same time.

A vital and sustainable source of income could and should be capturing the value of ecosystem services. Direct payments for ecosystem services, including through maintaining biodiversity and carbon sequestration, offer considerable promise for local communities in Madagascar (Wendland et al. 2010). It was hoped that carbon credits generated through photosynthetic carbon sequestration of the TAMS Project would be traded via the BioCarbon Fund of the World Bank (Martin et al. 2004, Aquino 2008, Ferguson 2009). These hopes were unfortunately stifled by the cancellation of the contract at the exact time when local communities should have reaped the fruit in form of payments for trees planted and carbon credits generated. Frustration caused among local communities by such donor-driven short-sighted decisions should not be underestimated. Unrealized expectations could eliminate previous achievements since it betrays trust. Yet, earning the trust of local communities and not letting them down is probably the most important prerequisite for successful community-based natural resource management in the first place.
In order to alter people's attitudes, it would be important to focus on increasing their understanding about, and appreciation for, the beauty and importance of the natural world. In order to anchor conservation in the minds of people, empowering them as parascientists and enthralling them in environmental education programs has been demonstrated to be particularly rewarding.

Finally, it should also not be forgotten that environmental degradation caused by local communities might not be exclusively driven by economic necessities. Alternatively, it is often considerably shaped by social and cultural dynamics within those communities (Hume 2006, Scales 2012). If natural resource management by local communities is to be successful, sociocultural contexts must therefore be considered. This is best assured by partners who support local communities in a longterm commitment, empowering them by giving them responsibility and a sense of pride.

\section{ACKNOWLEDGEMENTS}

Apart from the numerous donors that have supported our activities over the years, we would like to thank the Ministère de I'Environnement, de I'Ecologie, de la Mer et des Forêts (MEEMF) for continuous institutional support. We would also like to thank the local administrative representatives, including the Mayor of Andasibe and the présidents des fokontany. We are most grateful to the local community of Andasibe for their trust and companionship.

\section{REFERENCES}

Andreone, F., Carpenter, A.I., Cox, N., du Preez, L., Freeman, K., et al. 2008. The challenge of conserving amphibian megadiversity in Madagascar. PLoS Biology 6(5): e118:1-4. (doi:10.1371/journal.pbio.0060118)

ANGAP. 1995. Liste des plantes d'Andasibe. Association Nationale pour la Gestion des Aires Protégées. Unpubl. Report.

Angelsen, A. and Wunder, S. 2003. Exploring the forest-poverty link: key concepts, issues and research implications. CIFOR Occasional Paper No.40. Bogor, Indonesia, CIFOR. (doi:10.17528/cifor/001211)

Aquino, A. 2008. Madagascar: the Mantadia Biological Corridor REDD/AR project, BioCarbonFund Training, February, 8th 2008. Available at <http://goo.gl/HCRSna>

Ballet, J., Rakotohariniaina, B., Ramaroalison, S., Randrianalijaona, M. \& Tolizara, C. 2011. Vulne\# rabilite\# e\# conomique des populations et vulne\# rabilite\# des ressources forestie\# res: le cas d'Andasibe. In: Vulne\# rabilite\# , Inse\# curite\# Alimentaire et Environnement a\# Madagascar. J. Ballet \& M. Randrianalijaona (eds.), pp. 159-190. Editions L'Harmattan, Paris.

Cliquennois, N. 2007. Aperc\# u ge\# ne\# ral de la diversite\# des phasmes de Madagascar (Insecta, Phasmatodea). Le bulletin d' Arthropoda 32: 3-16.

Coomes, O. T., Takasaki, Y. and Rhemtulla, J. M. 2011. Land-use poverty traps identified in shifting cultivation systems shape long-term tropical forest cover. Proceedings of the National Academy of Sciences of the United States of America 108, 34 : 13925-13930. (doi:10.1073/pnas.1012973108)

Coutinho, J. B. 2007. Livelihoods, Conservation and Ethical Trade: A Baseline Study of Forest Margin Communities in the Commune of Andasibe, Eastern Madagascar. Unpubl. M.Sc Thesis. School of the Environment and Natural Resources, University of Wales, Bangor. 
Dolch, R. 2008. Sustainable natural resource management. The case of the Analamazaotra Forest Station, Andasibe, Madagascar. Monografie del Museo Regionale di Scienze Naturali di Torino 45: 377-384

Dolch, R. 2012. Species composition and relative sighting frequency of carnivores in the Analamazaotra rainforest eastern Madagascar. Small Carnivore Conservation 44: 44-47.

Dolch, R., Ratolojanahary, T., Randrianasolo, H., Rasolofoharivelo, T., King, T. and Randrianarimanana, L. 2013. Torotorofotsy-Ihofa. In: Lemurs of Madagascar: A Strategy for Their Conservation 2013-2016. C. Schwitzer, R. A. Mittermeier, N. Davies, S. Johnson, J. Ratsimbazafy, J. Razafindramanana, et al. (eds.), pp 71-73. IUCN/SSC Primate Specialist Group, Bristo conservation and Science Foundation, conservation International, Bristol, UK.

Dolch, R., Fiely, J. L., Ndriamiary, J. N., Rafalimandimby, J., Randriamampionona, R., Engberg, S. E. and Louis Jr., E. E. 2008. Confirmation of the greater bamboo lemur, Prolemur simus, north of the Torotorofotsy wetlands, eastern Madagascar. Lemur News 13: 14-17.

Dransfield, J. and Beentje, H. 1995. The Palms of Madagascar. Royal Botanic Gardens, Kew and The International Palm Society, Surrey, UK.

Dressler, W., Büscher, B., Schoon, M., Brockington, D., Hayes, T., et al. 2010. From hope to crisis and back again? A critical history of the global CBNRM narrative. Environmental Conservation 37, 1: 5-15. (doi:10.1017/S0376892910000044)

Edmonds, D., Rakotoarisoa, J. C., Dolch, R., Pramuk, J., Gagliardo, R., et al. 2012. Building capacity to implement conservation breeding programs for frogs in Madagascar: Results from year one of Mitsinjo's amphibian husbandry research and captive breeding facility. Amphibian and Reptile Conservation 5, 3: 57-69.

Ferguson, B. 2009. REDD comes into fashion in Madagascar. Madagascar Conservation \& Development 4, 2: 132-137. (doi:10.4314/mcd.v4i2.48654)

Fiely, J. L. 2010. Teaching and Leading through Science Research Education in Andasibe, Madagascar. Final Report to the Rufford Small Grants Foundation. Available at $<$ http://www.rufford.org/rsg/projects/jonathan_fiely>

Giacoma, C., Sorrentino, V., Rabarivola, C. and Gamba, M. 2010. Sex differences in the song of Indri indri. International Journal of Primatology 31, 4: 539-551. (doi:10.1007/s10764-010-9412-8)

Glaw, F. and Vences. M. 2007. A Field Guide to the Amphibians and Reptiles of Madagascar. Frosch-Verlag, Köln, Germany.

Gorenflo, L. J., Corson, C., Chomitz, K. M., Harper, G., Honzák, M. and Özler, B. 2011. Exploring the association between people and deforestation in Madagascar. In: Human Population: Its Influences on Biological Diversity. R. P. Cincotta and L. J. Gorenflo (eds.), pp 197-221. Springer Ecological Studies 214 Berlin \& Heidelberg, Germany. (doi:10.1007/978-3-642-167072_11)

Gruber, J. S. 2010. Key principles of community-based natural resource management: a synthesis and interpretation of identified effective approaches for managing the commons. Environmental Management 45: 52-66. (doi:10.1007/s00267008-9235-y)

Hockley, N. J. and Andriamarovololona, M. M. 2007. The economics of community forest management in Madagascar: is there a free lunch? USAID, Washington, D.C. <http://ow.ly/KW4gK> accessed 29 March 2015.

Hume D. 2006. Swidden agriculture and conservation in eastern Madagascar - stakeholder perspectives and cultural belief systems. Conservation and Society 4: 287-303.
Irwin, M. T., Wright, P. C., Birkinshaw, C., Fisher, B. L., Gardner, C. J., et al. 2010. Patterns of species change in anthropogenically disturbed forests of Madagascar. Biological Conservation 143, 10: 2351-2362. (doi:10.1016/j.biocon.2010.01.023)

IUCN. 2014. The IUCN Red List of Threatened Species. 2014.2. Available at <http://www.iucnredlist.org>

Janssen, T. and Rakotondrainibe, F. 2008. A revision of the indusiate scaly tree ferns (Cyatheaceae, Cyathea subgen. Alsophila sect. Alsophila) in Madagascar, the Comoros and the Seychelles. Adansonia 30, 2: 221-376.

Jensen, O. 2010. Social mediation in remote developing world tourism locations - the significance of social ties between local guides and host communities in sustainable tourism development. Journal of Sustainable Tourism 18, 5: 615-633. (doi:10.1080/09669581003615590)

Junge, R. E., Barrett, M. A. and Yoder, A. D. 2011. Effects of anthropogenic disturbance on Indri (Indri indri) health in Madagascar. American Journal of Primatology 73, 7: 632-642. (doi:10.1002/ajp.20938)

Kellert, S. R., Mehta, J. N., Ebbin, S. A. and Litchtenfeld, L. L. 2000. Community natural resource management: promise, rhetoric, and reality. Society and Natural Resources 13, 8: 705-715. (doi:10.1080/089419200750035575)

King, T., Ravaloharimanitra, M., Randrianarimanana, H. L., Rasolofoharivelo, M. T. and Chamberlan, C. 2013. Communitybased conservation of critically endangered lemurs at the Sakalava and Ranomainty sites within the AnkenihenyZahamena rainforest corridor, eastern Madagascar. Lemur News 17: 63-70.

Kremen, C., Cameron, A., Moilanen, A., Phillips, S. J., Thomas, C. D. et al. 2008. Aligning conservation priorities across taxa in Madagascar with high-resolution planning tools. Science 320 , 5873: 222-226. (doi:10.1126/science.1155193)

Louvel, M. 1909. La forêt d'Analamazaotra. Bulletin Economique de Madagascar 9: 313-349. Available at <http://goo.gl/BcCvmD>

Martin, N., Shoch, D., Dushku, A., Pearson, T. and Grimland. S. 2004. Measurement and Monitoring Plan for the MantadiaAndasibe Corridor Restoration and Conservation Carbon Project, Madagascar. Unpubl. Report. Winrock International Report to CELB of Conservation International, Arlington, VA, USA

Newsome, D. and Hassell, S. 2014. Tourism and conservation in Madagascar: The importance of Andasibe National Park Koedoe 56, 2: Art. \#1144. (doi:10.4102/koedoe.v56i2.1144)

Paiva, A. and Randrianarisoa, J. 2010. Partnership structures and project management in two reforestation initiatives: Emas, Brazil and TAMS, Madagascar. In: What is Needed to Make REDD+ Work on the Ground? Lessons Learned from Pilot Forest Carbon Initiatives. C. A. Harvey, O. Zerbock, S. Papageorgiou and A. Parra (eds.) p 32. Conservation International, Arlington, VA, USA.

Pawliczek, M. and Mehta, H. 2008. Ecotourism in Madagascar: How a sleeping beauty is finally awakening. In: Responsible Tourism - Critical Issues for Conservation and Development. A. Spenceley (ed.), pp 41-68. Earthscan, London.

Pirot, P. 2006. Olatra - Champignons d'Andasibe (Madagascar). Association Mitsinjo. Série Biodiversité d' Andasibe-Périnet (Madagascar) 1. Available at <http://goo.gl/mN2LEF>

Pollini J. 2009. Carbon sequestration for linking conservation and rural development in Madagascar: The case of the Vohidrazana-Mantadia Corridor Restoration and Conservation Carbon Project. Journal of Sustainable Forestry 28, 3-5: 322-342. (doi:10.1080/10549810902791507) 
Pollini, J. 2012. Understanding agricultural intensification on a forest frontier in Madagascar: elements for a Malthusian / Boserupian synthesis. In: Contested Agronomy: The Politics of Agricultural Research in a Changing World. J. Sumberg and J. Thompson (eds.), pp 116-130, Earthscan, Oxford.

Pollini, J., Hockley, N., Muttenzer, F. D., Ramamonjisoa, B. S. 2014. The transfer of natural resource management rights to local communities. In: Conservation and Environmental Management in Madagascar. I. R. Scales (ed.), pp 172-192, Routledge, New York.

Raik, D. B. and Decker, D. J. 2007. A multisector framework for assessing community-based forest management: Lessons from Madagascar. Ecology and Society 12, 1: 14. Available online at <http://www.ecologyandsociety.org/vol12/iss1/art14/>

Ramsar Convention. 2012. The Annotated Ramsar List: Madagascar. Available at <http://goo.gl/6Vx860>

Randrianarimanana, L., Ravaloharimanitra, M., Ratolojanahary, T., Rafalimandimby, J., Rasolofoharivelo, T., et al.. 2012. Statut et conservation de Prolemur simus dans les sites de Ranomainty et Sakalava du Corridor Ankeniheny-Zahamena. Lemur News 16: 2-7.

Ratolojanahary, T. H. 2011. Para-ecologist profile. Available at $<$ http://goo.gl/jrkLnh>

Ravaloharimanitra, M., Ratolojanahary, T., Rafalimandimby, J., Rajaonson, A., Rakotonirina, L., et al. 2011. Gathering local knowledge in Madagascar results in a major increase in the known range and number of sites for Critically Endangered Greater bamboo lemurs (Prolemur simus). International Journal of Primatology 32, 3: 776-792. (doi:10.1007/s10764011-9500-4)

Rendigs, A., Reibelt, L. M., Fidimalala, B. R., Ratsimbazafy, J. H. and Waeber, P. O. 2015. Ten years into the marshes - Hapalemur alaotrensis conservation, one step forward and two steps back? Madagascar Conservation \& Development 10, 1S: 13-20. (doi:10.4314/mcd.v10i1.S3)

Salafsky, N. and Wollenberg, E. 2000. Linking livelihoods and conservation: A conceptual framework and scale for assessing the integration of human needs and biodiversity. World Development 28, 8: 1421-1438.

Scales, I. R. 2012. Lost in translation: conflicting views of deforestation, land use and identity in western Madagascar The Geographical Journal 178, 1: 67-79. (doi:10.1111/j.14754959.2011.00432.x)

Toillier, A., Lardon, S. and Herve, D. 2009. An environmenta governance support tool: community-based forest management contracts (Madagascar). International Journal of Sustainable Development 11: 187-205.

Toillier, A. Serpantié, G., Hervé, D. and Lardon, S. 2011. Livelihood strategies and land use changes in response to conservation: Pitfalls of community-based forest management in Madagascar. Journal of Sustainable Forestry 30, 1-2: 20-56. (doi:10.1080/10549811003742357)

Torti, V., Gamba, M., Rabemananjara, Z. H. and Giacoma, C. 2013. The songs of the indris (Mammalia: Primates: Indridae): contextual variation in the long-distance calls of a lemur. Italian Journal of Zoology 80, 4: 596-607. (doi:10.1080/11250003.2013.845261)

Wallach, V. and Glaw, F. 2009. A new mid-altitude rainforest species of Typhlops (Serpentes: Typhlopidae) from Madagascar with notes on the taxonomic status of $T$. boettgeri Boulenger, $T$. microcephalus Werner, and T. capensis Rendahl. Zootaxa 2294: 23-38
Wendland, K. J., Honzák, M., Portela, R., Vitale, B., Rubinoff, S. and Randrianarisoa, J. 2010. Targeting and implementing payments for ecosystem services: Opportunities for bundling biodiversity conservation with carbon and water services in Madagascar. Ecological Economics 69, 11: 2093-2107. (doi:10.1016/j.ecolecon.2009.01.002)

Wesener, T. and Schütte, K. 2010. Swarming behaviour and mass occurrences in the world's largest giant pill-millipede species, Zoosphaerium neptunus, on Madagascar and its implication for conservation efforts (Diplopoda: Sphaerotheriida). Madagascar Conservation \& Development 5, 2: 89-94. (doi:10.4314/mcd.v5i2.63137)

Woodhead, C., Vences, M., Vieites, D., Gamboni, I., Fisher, B. L. and Griffiths, R. A. 2007. Specialist or generalist? Feeding ecology of the Malagasy poison frog Mantella aurantiaca. The Herpetological Journal 17, 4: 225-236.

\section{SUPPLEMENTARY MATERIAL}

AVAILABLE ONLINE ONLY.

Andasibe, a short history of the study site. 